\title{
クレゾールノボラック樹脂組成によるポジ型ホトレジストの パターンプロファイルへの影響
}

浅海慎五*、小原秀克、田中初幸、荒井喜晶、中山寿昌

Influence in the Pattern Profile of the Positive Photoresist by Components of the Novolak Resin

\author{
Shingo ASAUMI ${ }^{*}$, Hidekatsu KOHARA, Hatsuyuki TANAKA, \\ Yoshiaki ARAI and Toshimasa NAKAYAMA
}

Received June 6, 1987 ; Accepted October 23, 1987

1 粕 言

超LSIなど、半孪体整造プロセスては微編加工の精度 向上のために、ドライエッチングが採用されて、レジス ト寸法通りのエッチングが行われている。改細加工にお ける重要なポイントは、良好な断面形状の微細パターン を如何に再現性良く得るかにある。

$1 \mu \mathrm{m}$ のソククラフィーは、ステッパーとポジ型ホト レジストの組合せで行われており、更に $0.5 \mu \mathrm{m}$ のサブ ミクロンに问けて、光リングラフィーによるプロセスへ の逼用が倹討されている。

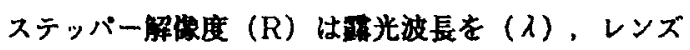
開口数を(NA) とすると

$$
\mathbf{R}=\mathbf{k} \lambda / \mathrm{NA}
$$

て表され、高解俚度化のためにG線（436 nm）に代わっ てI線(365 nm)"やエキシマレーザー2) など、芷光波 長の短波長化や高開口数"゙への湌㣙がなされている。

定数（k）はレジスト材料やブロセス条件の勘签を受 ける。ステッパーの解限界ては、マスクを透祸した光 はレジスト面に到䢖したときコントラストが低下する。

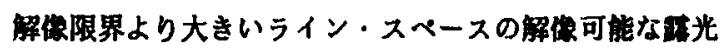
量ては、解限界のライン・スベースバターンは可光不 足になる。解限界のライン・スペースの解你可能な正 光量て証、より大きなライン・スベースパターンは而光 過多となって、スペースに較べてラインが細くなる。 入射光のコントラストを上げる方法としてCEL( Cont-

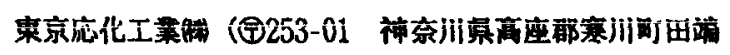
1590)

Tokyo Ohka Kogyo Co., Ltd. (1590 Tabata, Samakawacho, Koza-gun, Kanagawa-ken 253-01)

Key Word: Positive photoresist, pattern profile Cresol novolak resin rast Enhancement Layer )"があり、篮んに設されて いる。しかし、CEL の問題点として

(1) プロセスが複雑

（2）レジスト単居に輅へて西光時間が掛かりすぎる

（3）CELによってコントラストを上げても解媛度はホト レシストに左右される

などが挙げられ、ホトレジスト単屠て高解使度を狙う方 が有利てある。

ボジ型ホトレジストの高解像度化の一理として、前報ら にホトセンシタイザー量の影檍について報したが、ク レゾールノボラック榯脂の合成における原料の m- およ び p-クレゾールの湿合割合が、解像度に影紫を与える ことが見出したのて報告する。

\section{1 ホトレジスト}

\section{2 実惑}

クレソ゚ールノボラック楖脂の合成：クレゾールの異性 体の p-/用を 40/60，50/50，60/40の割合で湿合したの ち、をれぞれ $234 \mathrm{~g} は$ はかとり、37 พ\% ホルマリンの $207 \mathrm{~g}$ を混合してシュウ酸 $1 \mathrm{~g}$ 加えて $95 \mathrm{C} て 3$ 時間 反度した。避解した水分を拨取り、新たに水 $300 \mathrm{~cm}^{3}$ 加

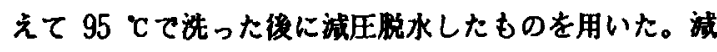
玩水の祭、温度を变えると末反応クレゾールも留出乙 た。クレゾールノボラック榯脂の分子量および残存クレ ソ゚ール量をTable 1 に示した。

ホトレジスト棝整：ホトセンシタイザーは 2.3.4ート j七ドロシベンゾフェノンーナフトキノンー1.2-シ アジトー5ースルホン酸エステル( $1: 1.6 \mathrm{~mol}$ 反応物 ) をホトレジスト組成物中に 23 W\%含むようにクレゾール

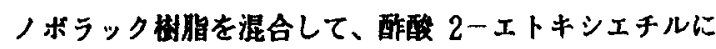
溶解した。粘度を $30 \mathrm{cP}$ 程整したのち、ミリポア社制 $0.2 \mu$ テフロンフィルターで遇してホトレジスト波 
にした。ホトレジストはクレゾールノボラック橵胉のク レゾールの混合割合によって p-/m- = 40/60を PR-40, 50/50をPR-50，60/40をPR-60と表す。ホトセンシ夕 イザー量は 23w\%を中心に 5 \%\%の筒囲て调量した。

\section{2 装璂书よび評洒条件}

\subsection{1 クレゾールノボラック樹脂の分析}

分子量の测定には、日立655 型波体クロマトグラフィ 一( 日立整作所) に GPCカラム Shodex KF-805, KF-

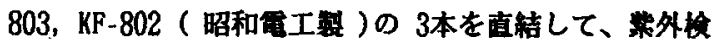
出器の波長を $280 \mathrm{~nm}$ で测定した。溶出波にはテトラヒ ドロフランを用いて、分子量はボリスチレン换算で表し た。

ボリマーの棒造は JNM-GX 400 型フーリェ变换核磁気

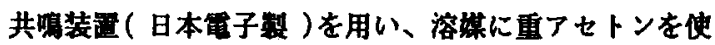
用して ${ }^{13} \mathrm{C}-\mathrm{NMR}$ スベクトルを测定した。

\subsection{2 ホトレジスト特性および断面形状}

基板书よび前処理 : 4 インチシリコンウェ八を 90 'c

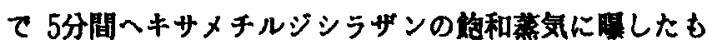
のを使用した。

ホトレジスト塑布およびプレデーク：TR-4000 型レジ ストコーター（東京応化裂）を使用して、スビンナー回

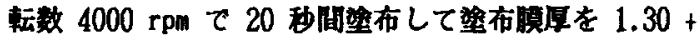
$0.02 \mu \mathrm{m}$ にそろえた。プレベーク条件は $110 \mathrm{C} て 90$ 种 間ホットブレート上て行った。

涪光：4800 DSW型ステッバー（米国 GCA社）を用いて マスクには自社オリジナルのデストチャートレチクルを 使用した。

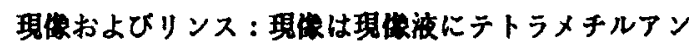
モニウムヒドロキシト 2.38 W\%水溶洨を用いて、現温 度 $23+1$ "C て浸清法て行った。リンスはイオン交俣水の 流水に 30 和間浸海した。

ホトレジストの䐜厚测定にはナノスベック(ナノメト リックス社繁)を用い、レジストバターンの断面形状の

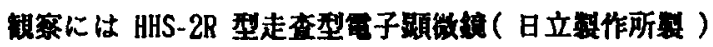
を使用した。

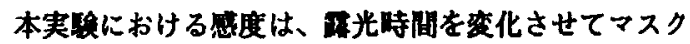
パターンを転写したとき、りェハ表面における路光部と 未路站のコントラストが 1 のパターン( $2 \mu \mathrm{m}$ ライン ・スペースより大きいパターン) の、スペース部分の䐜 厚が需になるときの正光時間 $D_{\mathbf{p}}$ で表した。

\section{3 結果と考察}

3.1 クレゾールノボラック榯脂の ${ }^{3}$ C - NMR スペクト ル

原料クレゾールのm-体およぴ
よるクレソ゚ールノボラック橲の ${ }^{13} \mathrm{C}-\mathrm{NMR}$ スペクトルの 棸化は、110-120 ppm に現れる。Fig.1 はクレッール， ボラック树脂の '3 C-NMR スヘトルの110-120 ppm を拡大 したものてあるが、ピークを(a)112.0-114.5 ppm，（b) 114.5-116.5 ppm，(c)116.5-119.0 ppmに区分すると、 Fig.2 に示したクレソ゚ールノボラック㯕脂の楼造式にお いて（a）は6-位岩素，(b) は2-位岩素，(c) は4-位炭素 てある。 Table 1 の $^{13} \mathrm{C}$-NMR スヘクトル分析結果は、P= (b) /(a)+(b)+(c) て表される ${ }^{3} \mathrm{C}-\mathrm{NMR}$ スペクトルのピー ク比てあるか、原料クレソ゚ールのp-体の溚度が高いはど ピーク比Pの値が大きなる。115.3 ppm のピークはpクレゾールの2-位书よび5-位炭素によるものてあるが、

残存クレッ゙ールの多いクレゾールノボラック踭脂活ど11 $5.3 \mathrm{ppm}$ のビークが大きい。-クレゾールはm-クレン゙ー ルに较へて反応性がしいのて、正クレッ゙ールとp-クレ ゾールの湿合物をホルマリンと縮合した場合、p-クレン゙ ールのほとんど全てが末反応物として残るためてあるあ

Table 1 Analytical results of various cresol novolak resins

\begin{tabular}{rrrrc}
\hline p-/m- & Mw & Mw/Mn & $\begin{array}{c}\text { Residual } \\
\text { cresol }\end{array}$ & $\begin{array}{l}\text { Analytical } \\
\text { result by } \\
1{ }^{3} \text { C-NMR }\end{array}$ \\
\hline 40/60 A & 8740 & 17.8 & 11.6 & 0.38 \\
B & 9200 & 9.1 & 1.0 & 0.32 \\
$50 / 50$ A & 8080 & 16.9 & 7.1 & 0.50 \\
B & 8790 & 10.0 & 1.3 & 0.43 \\
$60 / 40$ A & 6900 & 17.0 & 8.6 & 0.72 \\
B & 8850 & 10.4 & 0.8 & 0.59 \\
\hline
\end{tabular}

A: Crude resin, B: After removing free cresol

\section{2 感度および末理光の膈娍り}

m-クレゾールとp-クレゾールの混合割合を、变化させ て合成したノボラック榯脂を用いたホトレジストの感度 をFig.3に示した。p-クレゾールの請合が多いほと照度 が低下した。末反応クレン゙ールの多いクレゾール榯盟を 用いたホトレジスト、末反忘クレゾールの少ないクレ ゾール榯脂を用いたホトレジストの感度の有意さは見ら れなかった。末正光部の璄減りをFig.4に示したが、pクレソ゚ールの部合が多いほど膜減り量が少ない。

分子量の低いノボラック樹脂を用いたホトレジストの 感度は畆くなるのて、未反応クレゾールが多いと感度が 


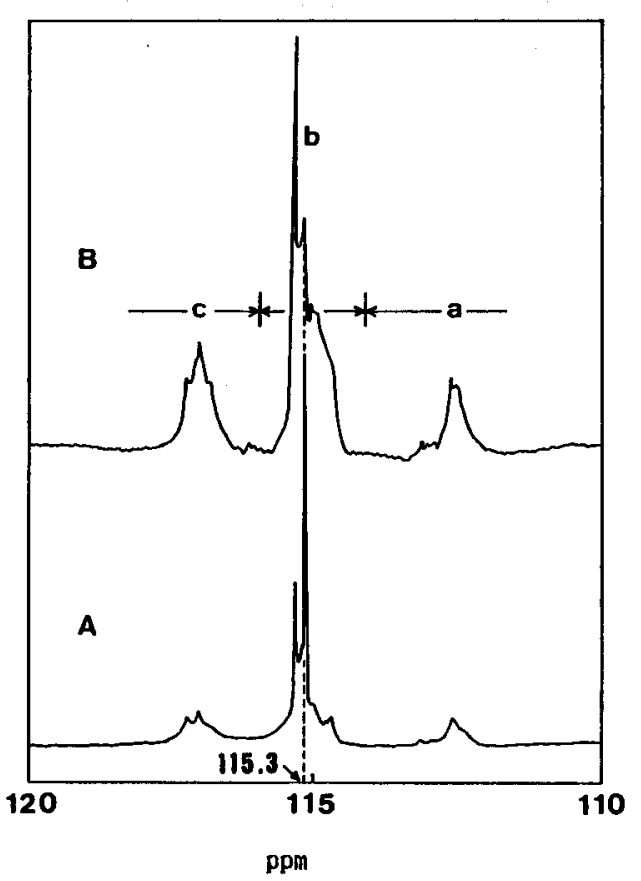

Fig. $1{ }^{13} \mathrm{C}$-NMR spectra of cresol novolak resins.

A: Crude resin, B: Af ter removing free cresol $115.3 \mathrm{ppm}$ shows peak for 2- or 5-position carbon of p-cresol.

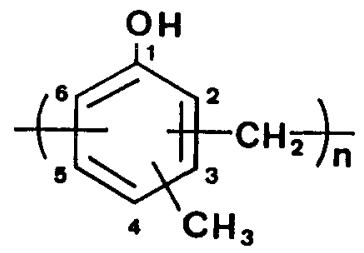

Fig.2 Chemical stracture of cresol novolak resin.

禹くなること予想されるが、p-クレゾールの多いクレゾ 一ルノボラック榯脂を用いたホトレジストは、未政光部 の脱娍り量が著しく少ないため、感度への影䇺は見られ ないと推定される。

\section{3 断面形状}

$1 \mu \mathrm{m}$ パターンの断面形状をFig.5 に示す。市服のポ ジ型ホトレジスト OFPR-800 は、バターントップに丸み

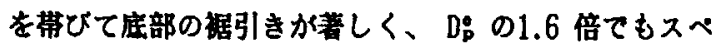
一ス部分が拔けない。PR-40 の断面形状は OFPR-800に 做ているか、 $\mathrm{D}_{p}^{\circ}$ の1.6 倍てスス゚ースは抜けている。こ れに対してPR-60 の断面形状はバターンエッジトップ部

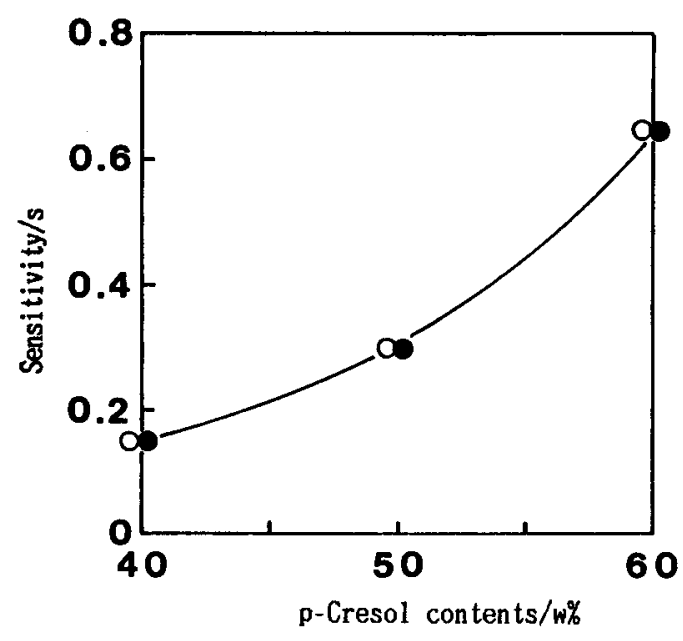

Fig. 3 Change in sensitivity by p-cresol contents of the novolak resin.

- : Crude resin, $O$ : Af ter removing free cresol

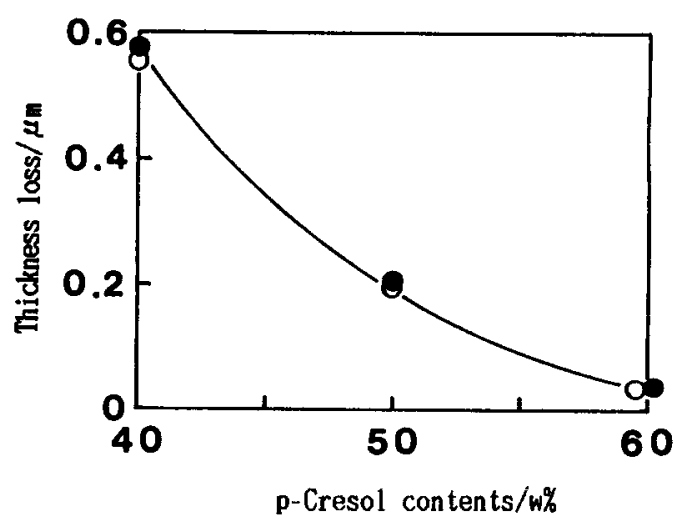

Fig. 4 Change in reduction of unexposed area by pcresol contents of novolak resin.

- : Crude resin, O: Af ter removing free cresol

分が竞く、底部の裾引きがみられない。p-クレゾールの 含有且の多いクレソ゚ールから合成されたノボラック榯脂 を用いたホトレジストほど、良い断面形状が得られる。

ホトセンシタイザー量を增すと断面形状が改善される 闻向にあり、mークレゾールの多いPR-40ではホトセンシ タイザー量 26w\% 以上でバーンエッシ底部の裾引きは

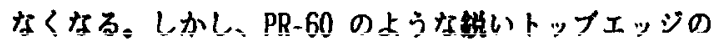
改善は見られない。ホトセンシタイザー量を少なくする と、䠑皇の变化によって寸法の変化が著しくなり、ホ トセンシタイザー量が多くなり過ぎると、現像のスべ ース部分に䑏䐜残りを生じ、センシタイザ一量 $23 w \%$ 前 後が㵊道てあった。 


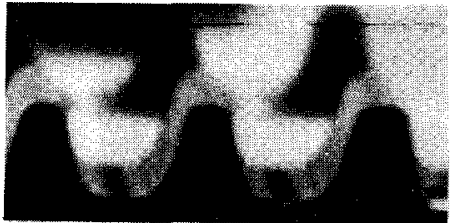

1.4

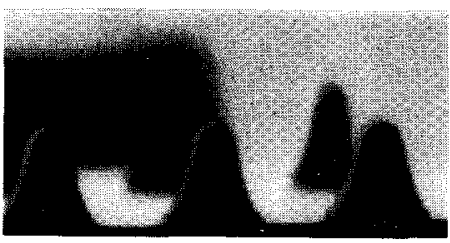

1.6

PR-40

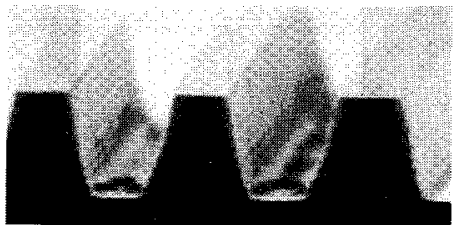

1.4

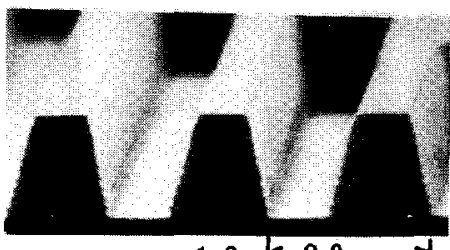

$1.6 \leqslant 2.0 \mu \mathrm{m} \rightarrow$

PR-60

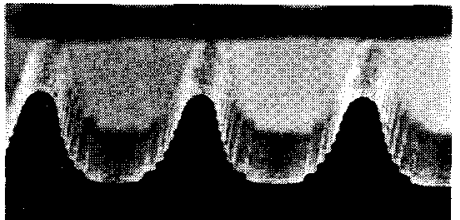

1.6

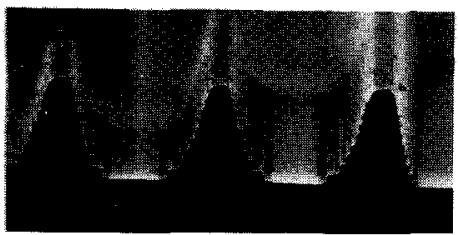

1.8

OFPR- 800

Fig.5 Pattern profiles at various exposure conditions.

$D_{\mathrm{p}}: \mathrm{PR}-40=150 \mathrm{~ms}, \mathrm{PR}-60=640 \mathrm{~ms}, 0 \mathrm{FPR}-800=360 \mathrm{~ms}$

Figures denote multiple of $D_{p}$.

$+5.0$
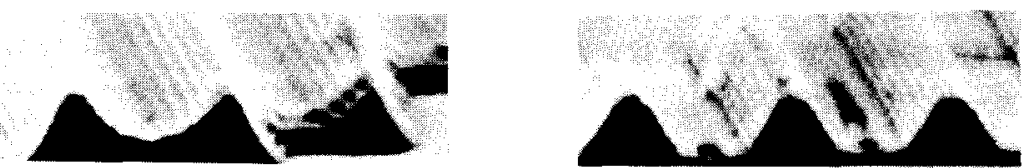

$+2.5$
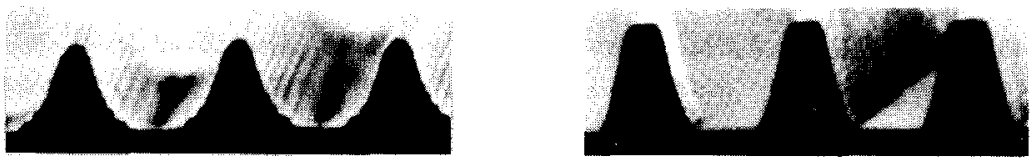

0
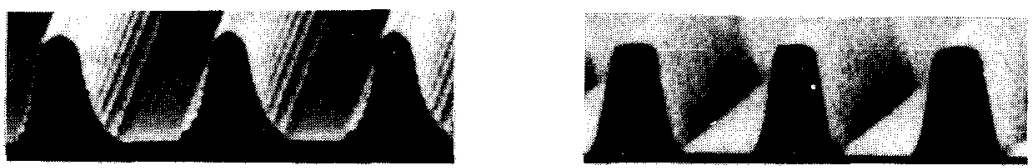

$-2.5$

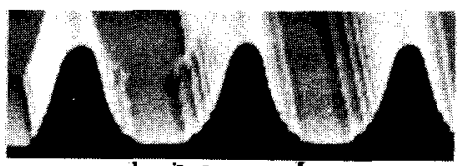

$-2.0 \mu m \rightarrow$

$-5.0$
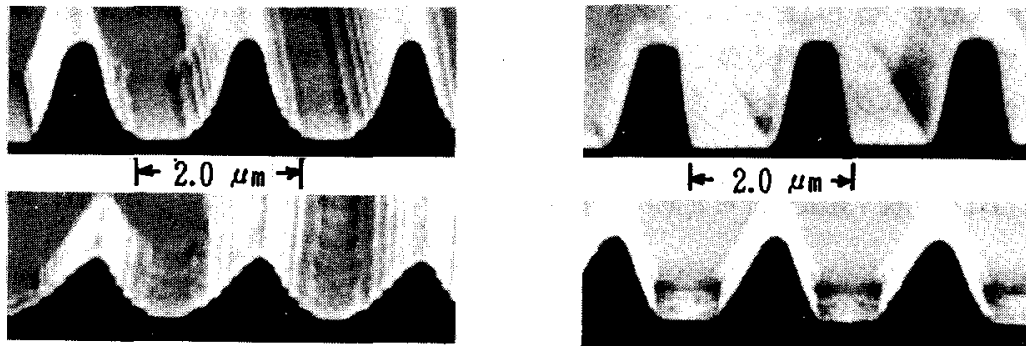

k. $2.0 \mu m+1$

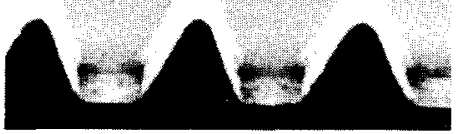

Defocus

OFPR-800

PR-60

Fig. 6 Influence of pattern profile by defocus.

p-クレゾールの含有量の多いボラック榯脂を用いたホ トレジストは、コントラスト增强效果か見られる。

PR-60 について、p-/m-=40/60 の混合クレゾールを原 料としたクレソ゚ール/ボラック树脂を用いた市販のホト レジストOFPR-800との比较て、ステッパーの焦点のずれ
による断面形状への影䇾をFig.6 に示すが、OFPR-800は 焦点のずれによって著しい断面形状の变化がみられるか、 PR-60 の変化は少ない。アルミニウム配線工程などの半 符体造の最終工程近くては、シリコンウェ八の表面に 段差を生じる。段差が大きく成れば成るほど、段差の上 


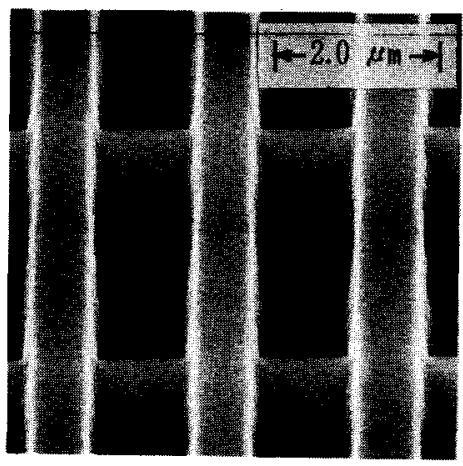

PR-60

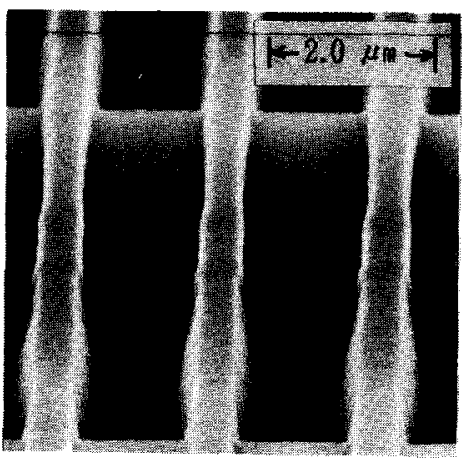

OFPR-800

Fig. 7 Line and space pattern on silicon oxide of $1 \mu \mathrm{m}$ step. Resist patterns are $1 \mu \mathrm{m}$ line and space.

部に焦点を合わせた場合、庭部は焦点が合わなくなる。 このような基板ては、段差に直角に交叉するホトレジス トバターンにリフラクティプノッチングを生じやすかか、

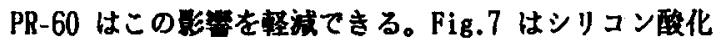
膜上てのバターニングの例でる。

\section{4 結 論}

レイリーの解你力の式 $\mathrm{R}=\mathbf{k} \lambda / \mathrm{NAKおいて} \mathrm{k}$ を小 さくすれば、雕力は向上する。ボジ型ホトレジストの ノボラック橴脂の p- クレゾール量を多くすることによ って断面形状が改善されるのて、k の值を小さくでる

p-クレッ゙ール量 60w\% のクレ・゙ールノボラック树脂 を用いたボジ型ホトレジストはバターンエッジは锐く、。

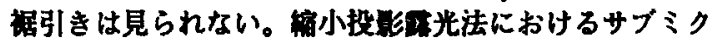
ロン領域で入射光の低下において、コントラスト増强 奻果を示して、さらに焦点深度も深くなり、超微城如工 に恖したがジ型ホトレジストと兽える。

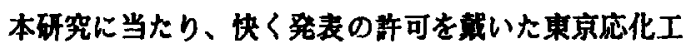

莱株式会社副社長中根久博士、および湖指学戴いた常杵 取縑役權田晃氏、NMR の测定をして戴いた岩佐杶氏、赛

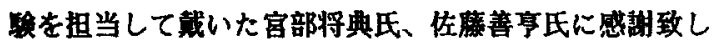
ます。

\section{文献}

1) H.L.Stover, M.Nagler, I.Boi and V.Miller, Proc. SPIE, 470, 22-23(1984)

2）日经マイクロデバイス 1987年 2月号，59-142

3) K.Ushida, M. Kameyama, S.Anzai, Proc. SPIE, 633, 17-23(1986)

4) B. F. Griffing and P. R. West, TECHNICAL PAPER REGIONAL TECHNICAL CONFERENCE "Photopolymers Principles - Processes and Materials" 185-192 (1982) 5）浅海䐜五、小原秀克、田中初幸、宫部将典、中山寿 㫤、㔍田 晃、中根 久，電気化学，54，(8) 701-706 (1986)

6) T. R. Pampalone, Solid State Technol., June, 115-120 (1984)，日本师, September, 79-85 (1984)

\section{Abstract}

The resolution, $R$, for the reduction projection printing method of the photolithography is expressed in $\mathbf{R}=\mathbf{k} \lambda / \mathrm{NA}$. The constant, $k$, is af fected by photoresist materials and photolithographic conditions. For higher resolution, it is important to decease $K$ value.

Af ter our study on the photoresist materials which are some of the elements giving inf luence to $k$, it has been found that positive photoresists with use of cresol novolak resin containing suffice of $p$-cresol, will show improved pattern profile. The $1 \mu \mathrm{m}$ pattern profile of positive photoresist with p-cresol for 60 w\%, obtained by a stepper $(N A=0.28, \sigma=0.7)$ had a sharp top and no tailing skirt on bottom of their edges. It is a positive photoresist which can give contrast enhancement effect and it is suitable for fine pattern work of submicron geometry. 